\title{
ANTHOCYANINS, PIGMENT STABILITY AND ANTIOXIDANT ACTIVITY IN JABUTICABA [Myrciaria cauliflora (Mart.) O. Berg] ${ }^{1}$
}

\author{
ANNETE DE JESUS BOARI LIMA², ANGELITA DUARTE CORREA ${ }^{2}$, ADELIR APARECIDA SACZK ${ }^{2}$ \\ MARIANA PEREIRA MARTINS ${ }^{3}$, RACHEL OLIVEIRA CASTILHO ${ }^{4}$
}

ABSTRACT- Different solvents were evaluated for the extraction of jabuticaba anthocyanin pigments, identifying, quantifying and verifying the stability of the anthocyanins, as well as the conduction of three antioxidant activity assays and determination of the vitamin $\mathrm{C}$ levels. The maceration with ethanol acidified with $\mathrm{HCl} 1.5 \mathrm{~mol} \mathrm{~L}^{-1}(85: 15)$ provides better pigment extraction and stability. The skin is anthocyanin rich,

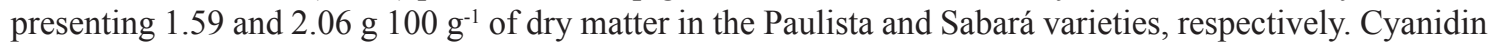
3 -glucoside is the majority pigment of the skins, followed by delphinidin 3-glucoside. The highest level of vitamin $\mathrm{C}$ was found in the skins and seeds of both varieties. It was verified that the skins, presented more antioxidant activity, in free radical capture, as well as in retarding the lipid oxidation process.

Index terms: jabuticaba, anthocyanin, method of extraction, vitamin C, antioxidant activity.

\section{ANTOCIANINAS, ESTABILIDADE DOS PIGMENTOS E ATIVIDADE ANTIOXIDANTE NA JABUTICABA [Myrciaria cauliflora (Mart.) O. Berg]}

RESUMO - Diferentes solventes foram avaliados para a extração de pigmentos antociânicos da jabuticaba, identificação, quantificação e verificação da estabilidade das antocianinas, assim como a condução de três testes de atividade antioxidante e determinação dos níveis de vitamina C. A maceração com etanol acidificado com $\mathrm{HCl} 1.5 \mathrm{~mol} \mathrm{~L}^{-1}$ (85:15) promoveu melhor extração e estabilidade dos pigmentos. As cascas são ricas em pigmentos antociânicos, apresentando 1,59 e 2,06 g $100 \mathrm{~g}^{-1}$ de matéria seca (MS) nas variedades Paulista e Sabará, respectivamente. Cyanidina 3-glucosideo é o pigmento majoritário nas cascas, seguido pela delphinidina 3-glucosideo. Os níveis de vitamina $\mathrm{C}$ foram mais altos nas cascas e sementes de ambas as variedades. Foi verificado que as cascas apresentaram maior atividade antioxidante, tanto na captura de radical livre, quanto no retardo do processo de oxidação lipídica.

Termos de indexação: jabuticaba, antocianina, método de extração, vitamina $\mathrm{C}$, atividade antioxidante.

\section{INTRODUCTION}

Jabuticaba is a Brazilian fruit of the family Myrtaceae, with the most wide spread varieties belonging to the genus Myrciaria. It is amply distributed, mainly in the south and southeast parts of Brazil and it is consumed in natura, in the form of liquor or jelly (GOMES, 1983).

The fruit is rich in polyphenols, mainly in the skin, which presents 11.18 and $11.99{\mathrm{~g} 100 \mathrm{~g}^{-1}}^{-1}$ of dry matter (DM) in the Paulista and Sabará varieties, respectively (LIMA et al., 2008). Among the polyphenols, the anthocyanins are pigments of the flavonoid class, responsible for the red, blue and purple coloration of many flowers and fruits.
The antioxidant activity of flavonoids in living beings has been proven by several researches and it has been verified that this property is dependent on the vegetable species, geographical origin and harvest time. The flavonoids have the capacity to inhibit and reduce the lesions caused by the free radicals in the cells which originate from the cellular metabolism (LIMA; GUERRA, 2003).

The evaluation of the antioxidant activity of the extract in vitro is an increasingly relevant aid in the areas of nutrition and food technology. Instead of determining the concentration of each antioxidant individually, the evaluation of the total antioxidant capacity shows itself to be more and more important adopting different methods. The antioxidant ac-

(Trabalho 199-10). Recebido em: 10-09-2010. Aceito para publicação em: 12-05-2011

${ }^{2}$ Prof $^{\mathrm{a}}$., Dr ${ }^{\mathrm{a}}$, Dept ${ }^{\mathrm{o}}$ de Química, UFLA, CP 3037, CEP: 37200-000, Lavras - MG.Brasil. E-mails: anneteboari@gmail.com; angelita@dqi.ufla.br; adelir@ufla.br

${ }^{3}$ Graduanda em Engenharia de Alimentos, Dep. de Ciência dos Alimentos,Universidade Federal de Lavras, CP 3037, CEP: 37200-000, Lavras - MG - Brasil. E-mail: maripereira7@gmail.com;

${ }^{4}$ Dra .,Dep. de Produtos Farmacêuticos, Faculdade de Farmácia, Universidade Federal de Minas Gerais, Av. Presidente Antônio Carlos, 6627, Câmpus Pampulha CEP: 31270-901 Belo Horizonte - MG - Brasil. E-mail: rocastilho@ig.com.br 
tivity is a measure of the capacity of the substances extracted from the matrix of foods and plants to sequester free radicals (ABTS and phosphomolybdenum test) or to delay the lipid oxidation process in a controlled system ( $\beta$-carotene/ linoleic acid system).

The increasing interest in using natural pigments in food in substitution of the artificial pigments, has led the researchers to study many methods of extraction of these pigments.

According to Francis (1989), several factors influence the stability of the anthocyanins, such as their chemical structure (number of hydroxyls, methylation degree and glycosylation); the $\mathrm{pH}$, temperature, light, presence of oxygen; enzymatic degradation; and interactions among other food components, such as ascorbic acid, metal ions, sugars, and copigments.

The extraction of anthocyanin from red vegetables is always done with solvents containing added acid to maintain the $\mathrm{pH}$ below 2 in order to prevent oxidation (LEES; FRANCIS, 1972; LEE; HONG, 1992). The anthocyanins are very soluble in polar solvents, being easily extracted with water, methanol and ethanol.

The aim of this study was to evaluate the best extraction techniques for identification and quantification of the anthocyanins and measurement of their stability, as well as the determination of vitamin $\mathrm{C}$ levels and conduction of antioxidant assays in the whole fruit and in the fractions of two jabuticaba varieties.

\section{MATERIAL AND METHODS}

\section{Samples}

Ripe jabuticabas of two varieties, Paulista and Sabará, classified as Myrciaria cauliflora (Mart.) O. Berg, were picked in the morning, at São José de Ismeril farm, in the town of Coqueiral, MG/Brasil. They were selected, washed, and sanitized with sodium hypochlorite $\left(200 \mathrm{mg} \mathrm{L}^{-1}\right)$ by immersion for 10 minutes, weighed and separated into whole fruits and into fractions (skin, pulp and seed) and each of those parts was weighed and separated to obtain three replicates. The part destined for whole fruit analysis was triturated in a blender for 2 minutes, frozen in portions of known weight, and lyophilized (freezedried) to constant weight. The fruits were crushed on a thick sieve, separating the skins, seeds and pulp that were later wrapped, weighed, frozen and lyophilized until constant weight.

\section{Experimental layout and statistical analysis}

The experiment was conducted in completely randomized design in a $4 \times 2$ factorial outline, analyzing 4 fractions being: whole fruit, skin, pulp and seed and 2 varieties of jabuticabas with 3 replicates.

The statistical analysis was made using the SISVAR program (FERREIRA, 2003). The averages were compared by the Scott-Knott test to 5\% of probability. For the anthocyanins stability data, the regression analysis was carried out by the quadratic method, using the Sigma Plot Software and a linear regression analysis to evaluate the relationship among the antioxidant activity and the polyphenol, anthocyanins and vitamin $\mathrm{C}$ levels.

\section{pigments}

Extraction and determination of anthocyanin

Initially $1 \mathrm{~g}$ of skin and $25 \mathrm{~mL}$ of water were used in triplicate, protected from light. The filtrate absorbance readings were taken at $1535 \mathrm{~nm}$, in a Micronal B 382 spectrophotometer. The extraction methodologies tested are showed in Table 1.

In the anthocyanin concentration calculations were taken into account the dilution factor and the cyaniding 3-galactoside coefficient of extinction (98.2) (Fuleki \& Francis (1968); Lees and Francis (1972), Equation 1.

Total anthocyanins $\left(\mathrm{mg}\right.$ cyanidin $\left.\mathrm{g}^{-1}\right)=$

$$
\frac{\text { Absorbance x dilution factor }}{98.2}
$$

After established the best extraction methodology, other solvents were evaluated: ethanol $95 \%$ P.A., aqueous ethanol solution $50 \%$, methanol $50 \%$ and acetone $30 \%$, using the volume of chosen extractor $(15$ or $25 \mathrm{~mL})$.

\section{Anthocyanin stability}

Ethanolic extracts at 50\% from the skins were distributed in test tubes $(20 \mathrm{~mL})$ and sealed. Half of the tubes were covered. All of the tubes were maintained at room temperature $\left(22 \pm 3^{\circ} \mathrm{C}\right)$ and at a distance of $1.32 \mathrm{~m}$ from $2-40 \mathrm{~W}$ fluorescent lamps. Initially the spectrophotometric readings were taken at $535 \mathrm{~nm}$ every $48 \mathrm{~h}$, and later, in intervals increased up to 185 days, with a total of 11 readings. The anthocyanin level was calculated according to (Equation 1). 


\section{HPLC analysis of anthocyanin}

The extracts were concentrated and submitted to purification, using $100 \mathrm{mg}$ solid phase extraction cartridges (SPE) C18, Supelclean Envi-18, from Supelco, conditioned with methanol acidified with $\mathrm{HCl}$ $1 \mathrm{~mol} \mathrm{~L}^{-1}$ (HONG; WROLSTAD, 1990) followed by Milli Q water. The samples were percolated through the cartridge with acidified methanol, filtered in 0.45 $\mu \mathrm{m}$ (Millipore) membranes, before injection into the chromatograph. The HPLC analysis were carried out using a HP1100 system (Agilent, USA), coupled to a quaternary pumps, an auto sampler, a programmable ultraviolet photodiode array detection (UV/DAD). An HPChemStation Systems software was used to assess and processing data. A ODS pre-column $(1 \mathrm{~cm}$ x $4.6 \mathrm{~mm}$ ID x $5 \mu \mathrm{m}$, Supelco Spherisorb) attached to a $\mathrm{C}_{18}$ column $(250 \times 4.6 \mathrm{~mm}$ ID $\times 5 \mu \mathrm{m}$, Nucleosil 120-5) were used at room temperature and flow rate $1 \mathrm{~mL} \mathrm{m^{-1 }}$. A linear gradient of acetonitrile (A) and 9\% acetic acid solution in Milli Q water (B) was used: 0 to $30 \%$ of the solvent $\mathrm{A}$ in $30 \mathrm{~min}$ at a flow rate of $1 \mathrm{~mL} \mathrm{~min}^{-1}$ and an injection volume of $20 \mu \mathrm{L}$ (PRATA; OLIVEIRA, 2007). Solvents used were of HPLC grade (J.T. Baker). Separated calibration curves were evaluated for cyaniding 3-glucoside, delphinidin 3-glucoside, peonidine 3-glucoside, petunidin 3-glucoside and malvidine 3-glucoside, (INRA-ECAN, UMR-Oenologie-Ampelologie, Villenave Dorrnon, France).

\section{HPLC determination of vitamin C}

The vitamin $\mathrm{C}$ was extracted using $0.5 \mathrm{~g}$ of lyophilized samples in $50 \mathrm{~mL}$ of oxalic acid and 0.1 $\mathrm{g}$ of infusorial earth, under agitation for $15 \mathrm{~min}$ in a horizontal agitator and filtered. The HPLC analysis were carried out using a Shimadzu LC 20 A, coupled to a quaternary pump, an auto sampler and UV-Vis detector. A Nucleosil pre-column ( 15 x $3.2 \mathrm{~mm}$ x 7.5 $\mu \mathrm{m}$ attached to a $\mathrm{C}_{18}$ column $(250 \times 4.6 \mathrm{~mm}$ ID $\times 5$ $\mu \mathrm{m}$, Nucleosil 120-5) were used at room temperature and flow rate of $1 \mathrm{~mL} \mathrm{~min}^{-1}$. As mobile phase, a buffer with pH 6.7 was used (sodium acetate $0.04 \mathrm{~mol} \mathrm{~L}^{-1}$, EDTA $0.05 \mathrm{~mol} \mathrm{~L}^{-1}$, tributyl ammonium phosphate $0.5 \mathrm{~mol} \mathrm{~L}^{-1}$ in isocratic mode, flow rate of $0.6 \mathrm{~mL}$ $\min ^{-1)}$ and a running time of $15 \mathrm{~min}$ for each sample (SILVA et al., 2009). Calibration curve was made with ascorbic acid, Vetec (1 to $100 \mathrm{mg} \mathrm{L}^{-1}$ ) for comparison of the retention times and quantification of vitamin $\mathrm{C}$ levels, in the whole-fruit extracts and fractions of the two jabuticaba varieties.

\section{Evaluation of antioxidant activity ABTS assay}

The methodology used for the determination of total antioxidant activity in fruits was described by $\mathrm{Re}$ et al., (1999), with additional modifications done carried out at the laboratories of the Empresa Brasileira de Pesquisa Agropecuária, EMBRAPA (2007).

The ABTS radical cation solution was prepared by the reaction of $5 \mathrm{~mL}$ of ABTS (acid 2,2'-azino-bis (3-etilbezotiazolin -6-sulphonic) stock solution $7 \mathrm{mmol} \mathrm{L}^{-1}$ (Sigma) and $88 \mu \mathrm{L}$ of potassium persulfate solution (Vetec) $140 \mathrm{mmol} \mathrm{L}^{-1}$, after incubation at room temperature in the dark for $16 \mathrm{~h}$. The formed radical was diluted in 50\% ethyl alcohol to obtain an absorbance of $0.70 \pm 0.05$ at $1734 \mathrm{~nm}$.

$3.0 \mathrm{~mL}$ of the $\mathrm{ABTS}^{-+}$radical was placed in a test tube with a $30 \mu \mathrm{L}$ aliquot of each extract dilution and homogenized in an agitator. The absorbance was measured in Micronal B 382 spectrophotometer, at $734 \mathrm{~nm}$ after 6 minutes of reaction, using 50\% ethyl alcohol, as a blank.

The ABTS value was determined by the comparison of the antioxidant degradation capacity in relation to Trolox ${ }^{\circledR}$ (Sigma) and to ascorbic acid (Vetec). It is calculated as the concentration of the antioxidant that supplies the same percentage of inhibition of Trolox ${ }^{\circledR}$ at $1 \mathrm{mmol} \mathrm{L}^{-1}$ (RE et al., 1999) and ascorbic acid at $100 \mathrm{mg} \mathrm{L}^{-1}$.

The calibration curves with ascorbic acid (10 to $200 \mathrm{mg} \mathrm{L}^{-1}$ ) and Trolox (100 to $2.000 \mu \mathrm{mol}$ $\left.\mathrm{L}^{-1}\right)$ were made and the positive control was rutin (Sigma).

\section{Phosphomolybdenum assay}

An aliquot of $0.3 \mathrm{~mL}$ of the diluted samples was added into $2.7 \mathrm{~mL}$ of the phosphomolybdic reagent (ammonium molybdate $4 \mathrm{mmol} \mathrm{L}^{-1}$, monobasic sodium phosphate $28 \mathrm{mmol} \mathrm{L}^{-1}$, sulfuric acid $0.6 \mathrm{~mol} \mathrm{~L}^{-1}$ ). It was used $50 \%$ ethanol as blank sample. The tubes were closed and taken to a water bath at $95{ }^{\circ} \mathrm{C}$ for $90 \mathrm{~min}$, cooled and the absorbance was read in Micronal B 382 UV spectrophotometer at $1695 \mathrm{~nm}$ (PRIETO et al., 1999). Each fraction was analyzed in the following concentrations: pulps, $4 \mathrm{mg} \mathrm{mL}^{-1}$, seeds, $2 \mathrm{mg} \mathrm{mL}^{-1}$, skins and whole fruit, $1 \mathrm{mg} \mathrm{mL}^{-1}$. The ascorbic acid (Vetec) was used as standard and the results were expressed as $\mathrm{mg} \mathrm{L}^{-1} \mathrm{~g}$ of dry matter.

\section{$\beta$-carotene/linoleic acid assay}

A stock solution of $\beta$-carotene/linoleic acid mixture was prepared as follows: $0.2 \mathrm{mg} \beta$-carotene - Sigma, was dissolved in $1 \mathrm{~mL}$ chloroform - Merck, linoleic acid - Fluka (40 mg) and Tween 20 - Sigma 
(400 mg) (emulsifier) were added. The chloroform was evaporated under nitrogen atmosphere and 100 $\mathrm{mL}$ of oxygen saturated water $(30 \mathrm{~min}$ ) was added with vigorous shaking until the emulsion became clear. In test tubes, $4.8 \mathrm{~mL}$ of that emulsion were added to $0.2 \mathrm{~mL}$ of each dilution of the sample (ethanolic extract) used for the test. For the blank, $4.8 \mathrm{~mL}$ of the emulsion and $0.2 \mathrm{~mL}$ of $50 \%$ ethanol was used and for the blank-sample $4.8 \mathrm{~mL}$ of water and $0.2 \mathrm{~mL}$ of diluted sample. They were done together with the samples. After homogenization, an absorbance was taken in the spectrophotometer at $470 \mathrm{~nm}$ time zero (initial). The tubes were then put in water bath at $50^{\circ} \mathrm{C}$ and sequential readings were taken every 20 minutes, for a total period of 2 hours. Trolox was used as positive control.

The degradation ratio (Rd) was evaluated for the control and for each sample or standard, according to the Equation 2 (SUJA et al., 2005):

$$
\mathrm{Rd}=\ln \left(\mathrm{A}_{0} / \mathrm{A}_{\mathrm{t}}\right) / \mathrm{t}
$$

Where $\mathrm{A}_{0}=$ initial absorbance of the sample, control or standard, at time $0, \mathrm{~A}_{\mathrm{t}}=$ the absorbance at time $(\mathrm{t})$, at which the extract no longer protects the sample, at $470 \mathrm{~nm}$.

The drop in the absorbance reading of the samples was correlated with the control and established the inhibition percentage of the lipid oxidation from the substrate, according to the Equation 3, where $\mathrm{AA}=$ Antioxidant Activity:

$\% \mathrm{AA}=(\mathrm{Rd}$ control $-\mathrm{Rd}$ sample $) / \mathrm{Rd}$ control $\mathrm{x}$ $100(3)$

\section{RESULTS AND DISCUSSION}

\section{Extraction}

The first extraction of the skin pigments was performed with the $\mathrm{HCl} 0.01 \mathrm{~mol} \mathrm{~L}^{-1}$ aqueous solution by agitation at different times, extracted from $53 \%$ to $57 \%$ of the total pigments. After the third extraction, the total amount of anthocyanins dropped to between $4.9 \%$ and $7.4 \%$. The total anthocyanins from the five extractions were $5.61 \pm 0.01 ; 5.37 \pm$ 0.11 and $4.99 \pm 0.04 \mathrm{mg} \mathrm{g}^{-1}$ of dry matter at $60 \mathrm{~min}$, $30 \mathrm{~min}$, and $15 \mathrm{~min}$, respectively. The total anthocyanin found, in dry matter, were $9.78 \pm 0.10$ and $8.40 \pm 0.26 \mathrm{mg} \mathrm{g}^{-1}$, respectively, for the extractions with maceration for $12 \mathrm{~h}$ at $4^{\circ} \mathrm{C}$ in acidified water with $\mathrm{HCl} 1.5 \mathrm{~mol} \mathrm{~L}^{-1}$ and $0.01 \mathrm{~mol} \mathrm{~L}^{-1}$. Comparing those results, it is verified that the maceration with distilled acidified water with $\mathrm{HCl} 1.5 \mathrm{~mol} \mathrm{~L}^{-1}$, presented a higher extraction yield.

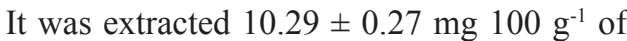
total anthocyanin for the volume of $15 \mathrm{~mL}$ of solvent while for $25 \mathrm{~mL}$ it was extracted only $9.78 \pm 0.1 \mathrm{mg}$ $100 \mathrm{~g}^{-1}$ of total anthocyanin. Therefore, the volume of $15 \mathrm{~mL}$ resulted in approximately 5\% more efficiency.

According to Markakis (1982), the $\mathrm{pH}$ has a markable influence on the color and stability of the anthocyanins, being more stable in more acid solutions and more quickly destroyed by heating. Tests conducted by Mazza (1995) showed that the total of extracted grape juice anthocyanins, went from 460

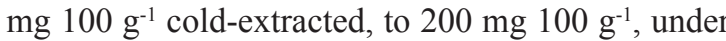
hot extraction.

In the other tested solvents, it was verified that the $95 \%$ ethanol $\left(21.08 \pm 0.77 \mathrm{mg} \mathrm{g}^{-1}\right)$ and $50 \%$ ethanol $\left(20.88 \pm 1.63 \mathrm{mg} \mathrm{g}^{-1}\right)$ were the ones that resulted in the highest extractability of the anthocyanins, followed by $30 \%$ acetone $\left(17.85 \pm 0.27 \mathrm{mg} \mathrm{g}^{-1}\right)$ and $50 \%$ methanol $\left(17.72 \pm 0.57 \mathrm{mg} \mathrm{g}^{-1}\right)$. Extraction with water resulted in the lowest extractability of the anthocyanins. It is verified that in spite of the anthocyanins being soluble in water, the less-polar solvents removed higher amounts of pigment from the sample.

The use of solvents with $\mathrm{HCl} 1.5 \mathrm{~mol} \mathrm{~L}^{-1}$ in jabuticaba propitiates a $\mathrm{pH}$ between 1 and 1.5. Therefore, in order to provide higher stability, it is important to keep the $\mathrm{pH}$ at $1.0 \pm 0.1$, during extraction of those pigments (LEES; FRANCIS, 1972).

\section{Pigment stability}

The pigment stability of $50 \%$ of ethanolic extract of jabuticaba skins was evaluated with and without light and storage time. Until the end of the experiment (185 days), the samples remained clear, without fungi or precipitate presence.

It can be observed in Figure 1 that the loss of total anthocyanins during the 185 days (more than 6 months) was $\pm 23 \%$ and that the light factor does not significantly affect the degradation of the anthocyanins.

Cabrita et al., (2000), studying the stability of anthocyanin pigments concluded that only the $\mathrm{pH}$ affects significantly the degradation of the anthocyanins, which was also verified by Abdel-Aal and Hucl (2003).

The anthocyanidins are less stable than the anthocyanins. The cyanidin 3-glycoside, presents a half-life into $0.01 \mathrm{~mol} \mathrm{~L}^{-1}(\mathrm{pH} 2.8)$ citric acid solution of 65 days, while its free aglycone reaches only 12 hours under the same conditions (IACOBUCCI; SWEENY, 1983). 
Determination of total anthocyanin by colorimetric method

The total anthocyanin in the skins was quite high, being $22.95 \%$ superior in the Sabará variety. The pulp and seed fractions presented relatively low anthocyanin levels, while the whole fruits presented an intermediate level (Table 2).

Bobbio et al. (2000) analyzing the açai fruit using the same method for extraction and quantification used in this study, found $263 \mathrm{mg} 100 \mathrm{~g}^{-1}$ of anthocyanin in the skin of the fresh fruit. Lima et al. (2005) found $16.2 \mathrm{mg} 100 \mathrm{~g}^{-1}$ of fresh matter of total anthocyanin in purple Surinam cherry. Zanatta et al.(2005), also found $54.0 \mathrm{mg} 100 \mathrm{~g}$-1 of total anthocyanin using the same extraction method in skin of fresh camu-camu, fruit of the same family as the jabuticaba. Transforming the jabuticaba skin anthocyanin dry matter to fresh matter, the Paulista has $383.0 \mathrm{mg} 100 \mathrm{~g}^{-1}$ and the Sabará $362.0 \mathrm{mg} 100$ $\mathrm{g}^{-1}$ of total anthocyanins. Therefore, the jabuticaba presented the highest levels, thus being able to be considered very rich in anthocyanins.

\section{Identification and quantification of anthocyanins by HPLC}

The anthocyanins, cyanidin 3-glucoside and delphinidin 3-glucoside were found in the skin of the two jabuticaba varieties. Cyanidin 3-glucoside was found in a small amount in the pulp (Table 3). The anthocyanin presence was not detected in the seeds of the studied varieties. The amount of the two anthocyanidins is practically the same for both varieties in the same fraction.

The results of total anthocyanins (colorimetric method) pointed that the skins of the Sabará variety is $29.0 \%$ superior than the Paulista variety (Table 2). However, under chromatographic analysis, this difference did not occur and anthocyanin results were higher than those from the colorimetric method. For this difference, the higher specificity of the chromatographic analysis should be taken into account.

Einbond et al. (2004) only found cyanidin 3 -glucoside, in methanolic extracts of jabuticaba (Myrciaria cauliflora). However, Trevisan et al. (1972) identified in the jabuticaba Sabará, by paper chromatography peonidine and peonidine 3-glucoside.

\section{Vitamin C}

The skins presented the highest concentration of vitamin $C$ in both varieties and seeds presented superior concentration to those of the pulp (Table 4).

In the Brazilian Table of Food Composition (TACO, 2006), the vitamin C content in fresh jabuticaba pulp is $16.2 \mathrm{mg} 100 \mathrm{~g}^{-1}$. Hernandez et al. (2006), evaluating vitamin $C$ in fresh fruits by different methods, found for orange $66 \mathrm{mg} 100 \mathrm{~g}^{-1}$ and for papaya $149 \mathrm{mg} 100 \mathrm{~g}^{-1}$. They used a solution of metaphosphoric and acetic acid as extractor and HPLC analysis. Odriozola-Serrano et al. (2007)

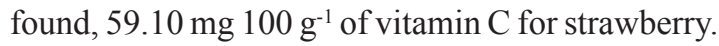
This fruit has higher vitamin $\mathrm{C}$ content, among those analyzeExpressing the results of this present work into fresh matter, those contents would become for $59.50 ; 26.29 ; 60.55$; and $43.57 \mathrm{mg}_{100 \mathrm{~g}^{-1}}$ in the skin, pulp, seed and whole fruit, respectively, for the Paulista variety and $47.00 ; 25.21 ; 60.58$ and

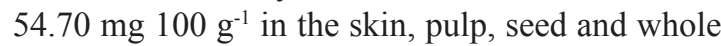
fruit, respectively, for the Sabará variety. Thus, the vitamin $C$ concentration found in the pulps of the two jabuticaba varieties was superior to those found by TACO (2006). It could be due to the harvest time, maturing and irrigation, among other factors. It is also verified that those contents are usually found in fruits, but not as high as the vitamin $\mathrm{C}$ rich fruits, such as the acerola, which contains $1,500{\mathrm{mg} 100 \mathrm{~g}^{-1}}^{-1}$ (YAMASHITA et al., 2003).

The recommended daily intake (RDI) of vitamin $\mathrm{C}$ is $60 \mathrm{mg}$. The ingestion of $100 \mathrm{~g}$ of jabuticaba pulp in natura (fraction with smaller levels of vitamin) represents $41.67 \%$ of the daily requirements, a quite satisfactory percentage. The seeds and skins are also shown to be good vitamin sources C, being able to be used for the enrichment of foods and cosmetics.

\section{Evaluation of antioxidant activity ABTS assay}

The skin of the Sabará variety presented higher antioxidant activity when compared to the Paulista variety, in Trolox ${ }^{\circledR}$ equivalent, $2.06 \mathrm{mmol}$ $\mathrm{L}^{-1} \mathrm{~g}^{-1}$ of dry matter, as well as ascorbic acid, 146.63 $\mathrm{mg} \mathrm{g}^{-1}$ of dry matter. The pulps and the seeds presented the lowest antioxidant activities equivalent to Trolox ${ }^{\circledR}$ in the two varieties, while in the whole fruit the values of activity was intermediate (Table 5).

Considering that the two anthocyanins found in the jabuticaba variety skins studied, cyanidin 3-glucoside and delphinidin 3-glucoside, present hydroxyl groups in their structures at the $5,7,3$ ' and $4{ }^{\circ}$ positions in cyanidin and at the $5,7,3$ ', 4 ' and 5' positions in the delphinidin, a better result would be expected. However, the delphinidin levels were very low compared to those of cyanidin (Table 3) and they also are not found in the isolated form as the standards. 
The higher antioxidant capacity of the delphinidin over the cyanidin was proven experimentally by Kuskoski et al. (2004).

According to Heim et al. (2002), the free radical capture capacity is attributed primarily to the high reactivity of hydroxyl substituents of the flavonoid structure. The hydroxyl presence and position in the B ring, 3' and 4', is the most significant factor of the capture of reactive oxygen (ROS) and nitrogen (RNS) species, because it confers a high stability to the formed radical. Therefore, the presence and the total number of hydroxyl groups, substantially influence in the several mechanisms of antioxidant activity.

The jabuticaba seeds showed relatively low anthocyanins contents (Table 2), but with considerable antioxidant capacity, it seems that other substances present in the seeds could be exercising such capacity.

\section{Phosphomolybdenum Assay}

The skins presented a higher antioxidant capacity by the phosphomolybdenum assay, being superior in the Paulista variety, different from the ABTS assay, which showed higher activity in the skins of the Sabará variety (Table 5). The fractions presented differentiated antioxidant capacity results. The pulps showed lower activity. The fruit of the two jabuticaba varieties presented high antioxidant activity, mostly in the skin, but lower than that presented by the rutin. The ethanolic extracts of the different parts of the fruit demonstrated to have different levels of antioxidant activity, as in the ABTS assay.

Kubola and Siriamornpun (2008), evaluating the antioxidant activity of different parts of the Momordica charantia L. plant also found that the performance of the assays depends on the part of the plant. It shows that each sample have different antioxidant activities which responds differently according to the used assay.

\section{B-carotene/linoleic acid assay}

The results of inhibition of the lipid oxidation by the ethanolic extracts were grouped, in the system $\beta$-carotene/linoleic acid, in 3 extract concentrations (Table 6). In the Sabará variety, all of the fractions presented the same antioxidant activity, for the concentration of $2 \mathrm{mg} \mathrm{mL}^{-1}$, a concentration that was common to all of the fractions. However, in the Paulista, the pulp demonstrated lower inhibition of the linoleic acid oxidation than the other samples. Among the varieties, occurred a significant difference $(p \leq 0,05)$ of antioxidant activity only in the pulp, in which the Sabará variety presented higher inhibition of the lipid oxidation.

The antioxidant activity can be due to the presence of large amount of anthocyanin pigments (skin and whole fruit) and to the synergistic effect of the other substances present in the extracts as well as vitamin $\mathrm{C}$, mainly in the pulp and seeds, which present low pigments concentrations. Fruits such as grape, 'Bengal' litchi, mango and pear presented higher antioxidant activity in the seeds than in the pulps in tests conducted by Guo et al. (2003). According to the authors, in spite of the grape seeds being rich in proanthocyanidins, in the literature there is no other data which can explain this higher antioxidant activity in the seeds. It can be said that the jabuticaba presents high antioxidant activity, inhibiting or delaying the lipid oxidation, demonstrated in the $\beta$-carotene/ linoleic acid test.

The use of several antioxidant methods allows higher precision in the indication of the antioxidant potential of the fruit. Interactions among antioxidants can present effects that would not be observed when the elements are tested separately (BORGUINI; SILVA, 2007).

\section{Relationship among antioxidant compounds and antioxidant activity}

To evaluate the relationship among the antioxidant assays and the polyphenols (data obtained from Lima et al., 2008), anthocyanins (Table 2) and vitamin C (Table 4), of the Sabará variety, it was carried out a linear regression analysis and its precision appraised with $\mathrm{R}^{2}$ (Table 7 ). The ABTS, antioxidant assay, Trolox $\AA$, and vitamin $C$ equivalent, had higher $\mathrm{R}^{2}$ coefficients $(0.91$ and 0,87 for polyphenols, 0,69 and 0,63 for anthocyanins, and 0,74 and 0,73 for Vitamin $C$ results, respectively). Based on these results, it can be seen that polyphenol contents were better associated with ABTS assay Trolox equivalent $(r=0,95)$. On the other hand, the $\beta$-carotene/linoleic acid assay method had very low $\mathrm{R}^{2}$ with the analyzed variables.

According to Heim et al. (2002), the phenolic compounds play a role in the antioxidant activity in fruits, which can be observed in the skins, which present higher antioxidant activity and higher amount of phenolic compounds.

Kubola and Siriamornpun (2008) also did not find significant correlation between total phenolics and the $\beta$-carotene/linoleic acid assay, in Momordica charantia $\mathrm{L}$. fruit.

Vitamin $\mathrm{C}$ is the most abundant hydro soluble antioxidant in plants. However, some antioxidant assays have revealed low antioxidant activity in fruits and vegetables rich in vitamin $\mathrm{C}$, demonstrating 
that the vitamin $C$ can present a pro-oxidant action (DUARTE-ALMEIDA et al., 2006).

The acerola, for instance, in spite of the high anthocyanin concentration, presented low antioxidant activity in the $\beta$-carotene/linoleic acid assay. The low contribution of the vitamin $\mathrm{C}$ in antioxidant assays was also verified previously (HASSIMOTTO et al., 2005). Duarte-Almeida et al. (2006) also verified that the acerola (rich in vitamin C) presented high antioxidant activity in the DPPH radical scavenging assay and low activity in the $\beta$-carotene/ linoleic acid system, differently from the açaí that, with lower vitamin $\mathrm{C}$ levels and higher anthocyanins, presented the highest inhibition percentage of the lipid oxidation in the $\beta$-carotene/linoleic acid system and inferior antioxidant activity in the DPPH assay. This result demonstrated a positive relationship between polyphenols and antioxidant activity. That study demonstrated that the antioxidant activity can be determined using several antioxidant systems. However, there are various methodological limitations for the determinations. For the jabuticaba the ABTS test presented a better relationship related to the polyphenols, anthocyanins and vitamin C.

More studies should be conducted seeking pigment isolation, with higher stability, so that the fruit can be better used, aggregating value and thus decreasing the waste of the non-consumable parts.

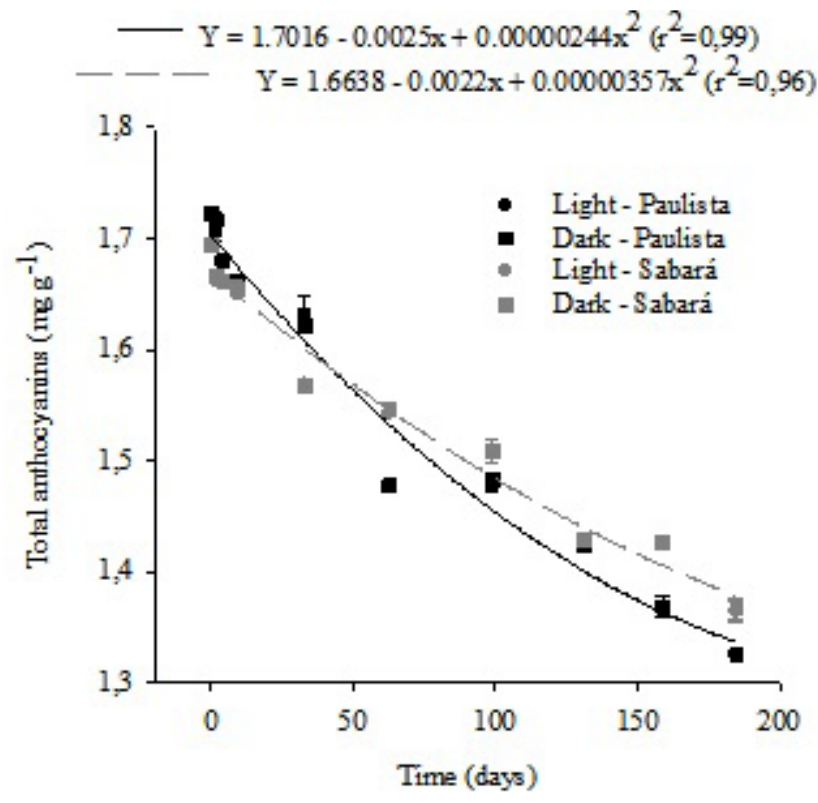

FIGURE 1 - Anthocyanins from the skins of two varieties of jabuticaba, stored at room temperature in the presence and absence of light. Dry matter. Regression analysis was conducted through quadratic model, using the software Sigma Plot.

TABLE 1 - Different extractions methods of anthocyanins pigments.

\begin{tabular}{|c|c|c|c|}
\hline Method & Extraction conditions & Extractor & Reextraction/washing \\
\hline $\begin{array}{l}\text { Jing \& Giusti } \\
\text { ( 2007), modified }\end{array}$ & $\begin{array}{c}\text { Agitation at } 50^{\circ} \mathrm{C} \text { at } \\
15,30,60 \mathrm{~min}\end{array}$ & $\mathrm{HCl} 0,01 \mathrm{~mol} \mathrm{~L}^{-1}$ & $\begin{array}{l}4 \text { consecutive reextractions and the } \\
\text { absorbance was measured in each } \\
\text { extract }\end{array}$ \\
\hline $\begin{array}{l}\text { Lees \& Francis } \\
(1972) \text {, modified }\end{array}$ & $\begin{array}{c}2 \text { min of politron-agitation } \\
\text { and then maceration for } \\
12 \mathrm{~h} \text {, at } 4^{\circ} \mathrm{C}\end{array}$ & $\begin{array}{c}\text { acidified water } \\
(85 \% \text { water for } 15 \% \\
\left.\text { of } \mathrm{HCl} 1.5 \mathrm{~mol} \mathrm{~L}^{-1}\right)\end{array}$ & Residue washed to $200 \mathrm{~mL}^{*}$ \\
\hline $\begin{array}{l}\text { Lees \& Francis } \\
\text { (1972), modified }\end{array}$ & Maceration for $12 \mathrm{~h}$, at $4^{\circ} \mathrm{C}$ & $\mathrm{HCHCl}$ 0,01 $\mathrm{mol} \mathrm{L}^{-1}$ & $\begin{array}{l}2 \text { reextractions for } 15 \mathrm{~min} .\left(25^{\circ} \mathrm{C}\right) \\
\text { under agitation and residue washed } \\
\text { to } 200 \mathrm{~mL}^{*}\end{array}$ \\
\hline
\end{tabular}

*An aliquot of $2 \mathrm{~mL}$ was removed and placed in a $100 \mathrm{~mL}$ flask and the volume completed with the solvent. After $2 \mathrm{~h}$ at room temperature the absorbance was measured. 
TABLE 2 - Total anthocyanins in the whole fruit and fractions of two varieties of jabuticaba, in $\mathrm{mg} \mathrm{g}^{-1}$ dry matter.

\begin{tabular}{ccc}
\hline Sample & Paulista $^{*}$ & Sabará $^{\mathrm{a}}$ \\
\hline Skin & $15.85 \pm 0,74^{\mathrm{cA}}$ & $20.57 \pm 0.66^{\mathrm{cB}}$ \\
Pulp & $0.09 \pm 0.00^{\mathrm{aA}}$ & $0.10 \pm 0.02^{\mathrm{aA}}$ \\
Seed & $0.35 \pm 0.02^{\mathrm{aA}}$ & $0.31 \pm 0.02^{\mathrm{aA}}$ \\
Whole fruit & $5.83 \pm 0.68^{\mathrm{bA}}$ & $8.37 \pm 0.72^{\mathrm{bB}}$ \\
\hline CV (\%) & \multicolumn{2}{c}{7.75} \\
\hline
\end{tabular}

${ }^{(*)}$ Data are the average of 3 replicates \pm standard deviation.

Lowercase letters in the column compare between fractions and capital letters on the line compare between the varieties. The same letters do not differ by Scott-Knott test at 5\% probability.

TABLE 3 - Quantification of anthocyanins ( $\mathrm{mg} \mathrm{g}^{-1}$ dry matter) in the skin and pulp of two varieties of jabuticaba by HPLC at $520 \mathrm{~nm}$.

\begin{tabular}{ccc}
\hline Variety & $\begin{array}{c}\text { Cyanidin } \\
\text { 3-glucoside }\end{array}$ & $\begin{array}{c}\text { Delphinidin }^{\text {a }} \\
\text { 3-glucoside }\end{array}$ \\
\hline \multicolumn{3}{c}{ 'Paulista' } \\
\hline Skin & $25.82 \pm 1.14$ & $3.09 \pm 0.26$ \\
Pulp & $0.18 \pm 0.04$ & $0.00 \pm 0.01$ \\
\hline \multicolumn{3}{c}{ 'Sabará' } \\
\hline Skin & $25.98 \pm 2.78$ & $2.71 \pm 0.29$ \\
Pulp & $0.07 \pm 0.00$ & $0.00 \pm 0.00$ \\
\hline
\end{tabular}

*Data are the average of 3 replicates \pm standard deviation.

TABLE 4 - Quantification of vitamin C (mg $100 \mathrm{~g}^{-1}$ dry matter) by HPLC, in the whole fruit and its fractions of two varieties of jabuticaba.

\begin{tabular}{lcc}
\hline \multicolumn{1}{c}{ Sample } & 'Paulista' & 'Sabará' \\
\hline Skin & $246.28 \pm 9.2^{\mathrm{bA}}$ & $298.23 \pm 40.5^{\mathrm{cA}}$ \\
Pulp & $163.38 \pm 7.56^{\mathrm{aA}}$ & $167.54 \pm 1.42^{\mathrm{aA}}$ \\
Seed & $204.78 \pm 12.81^{\mathrm{bA}}$ & $212.40 \pm 18.02^{\mathrm{bA}}$ \\
Whole fruit & $221.76 \pm 40.40^{\mathrm{bA}}$ & $265.68 \pm 4.17^{\mathrm{cB}}$ \\
\hline \multicolumn{2}{c}{ CV (\%) } & \multicolumn{2}{c}{10.69} \\
\hline
\end{tabular}

Data are the average of 3 replicates \pm standard deviation. Lowercase letters in the column compare between fractions and uppercase letters on the line compare between the varieties. The same letters do not differ by Scott-Knott test at $5 \%$ probability.

TABLE 5 - Antioxidant activity of ethanol extracts of whole fruit and its fractions (dry matter) of two varieties of jabuticaba and of two standards, determined by ABTS and phosphomolybdenum assay.

\begin{tabular}{|c|c|c|c|}
\hline \multirow[b]{2}{*}{ Variety } & \multicolumn{2}{|c|}{ ABTS } & \multirow{2}{*}{$\begin{array}{c}\text { Phosphomolybdenum } \\
\text { Equivalent to } \\
\text { vitamin } C\end{array}$} \\
\hline & Equivalent to Trolox ${ }^{\circledR}$ & Equivalent to vitamin $\mathrm{C}$ & \\
\hline 'Paulista' & $\mathrm{mmol} \mathrm{L}^{-1} \mathrm{~g}^{-1}$ & $\mathrm{mg} \mathrm{g}^{-1}$ & $\mathrm{mg} \mathrm{g}^{-1}$ \\
\hline Skin & $1.56 \pm 0.13^{\mathrm{dA}}$ & $99.99 \pm 2.76^{\mathrm{cA}}$ & $159.73 \pm 11.48^{\mathrm{dB}}$ \\
\hline Pulp & $0.08 \pm 0.01 \mathrm{aA}$ & $6.06 \pm 0.77 \mathrm{aA}$ & $29.18 \pm 0.75$ aA \\
\hline Seed & $0.92 \pm 0.08^{\mathrm{bA}}$ & $67.73 \pm 4.27^{\mathrm{bA}}$ & $68.58 \pm 0.92^{\mathrm{bA}}$ \\
\hline Whole fruit & $1.20 \pm 0.11^{\mathrm{cA}}$ & $97.28 \pm 7.28^{\text {c } \mathrm{B}}$ & $113.53 \pm 18.8^{\mathrm{cA}}$ \\
\hline \multicolumn{4}{|l|}{ 'Sabará' } \\
\hline Skin & $2.06 \pm 0.02^{\mathrm{cB}}$ & $146.63 \pm 0.95^{\mathrm{cB}}$ & $142.89 \pm 4.06^{\mathrm{dA}}$ \\
\hline Pulp & $0.09 \pm 0.01^{\mathrm{aA}}$ & $6.67 \pm 0.85^{\mathrm{aA}}$ & $32.64 \pm 2.27 \mathrm{aA}$ \\
\hline Seed & $1.1 \pm 0.26 \mathrm{bA}$ & $76.89 \pm 12.30^{\mathrm{bA}}$ & $66.10 \pm 1.28^{\mathrm{bA}}$ \\
\hline Whole fruit & $1.21 \pm 0.06^{\mathrm{bA}}$ & $82.14 \pm 2.79^{\mathrm{bA}}$ & $127.56 \pm 3.23^{\mathrm{cA}}$ \\
\hline CV (\%) & 11.38 & 7.51 & 8.72 \\
\hline Rutin & $3.45 \pm 0.03$ & $255.60 \pm 2.77$ & $290.89 \pm 15.7$ \\
\hline
\end{tabular}

Data are the average of 3 replicates \pm standard deviation. Lowercase letters in the column compare between fractions and uppercase letters on the line compare between the varieties. The same letters do not differ by Scott-Knott test at $5 \%$ probability. 
TABLE 6 - Antioxidant activity of whole fruit and its fractions (in dry matter) of two varieties of jabuticaba by the $\beta$-carotene/ linoleic acid assay.

\begin{tabular}{|c|c|c|c|c|c|}
\hline $\begin{array}{l}\text { Variety } \\
\text { Paulista }\end{array}$ & $\begin{array}{l}\text { Concentration } \\
\left(\mathrm{mg} \mathrm{mL}^{-1}\right)\end{array}$ & $\begin{array}{c}\text { Oxidation Inhib. } \\
(\%)\end{array}$ & $\begin{array}{l}\text { Variety } \\
\text { Sabará }\end{array}$ & $\begin{array}{l}\text { Concentration } \\
\left(\mathrm{mg} \mathrm{mL}^{-1}\right)\end{array}$ & $\begin{array}{c}\text { Oxidation Inhib. } \\
(\%)\end{array}$ \\
\hline \multirow[t]{3}{*}{ Skin } & 2 & $76.0 \pm 2.40^{\mathrm{bA}}$ & Skin & 2 & $72.72 \pm 4.74^{\mathrm{aA}}$ \\
\hline & 1 & $75.02 \pm 5.52$ & & 1 & $70.80 \pm 4.58$ \\
\hline & 0.5 & $71.33 \pm 5.75$ & & 0.5 & $64.61 \pm 4.62$ \\
\hline \multirow[t]{3}{*}{ Pulp } & 4 & $57.05 \pm 3.14$ & Pulp & 4 & $69.26 \pm 5.87$ \\
\hline & 2 & $48.44 \pm 4.19^{\mathrm{aA}}$ & & 2 & $66.83 \pm 7.50^{\text {а в }}$ \\
\hline & 1.33 & $44.11 \pm 3.50$ & & 1.33 & $59.81 \pm 9.08$ \\
\hline \multirow[t]{3}{*}{ Seed } & 4 & $80.01 \pm 2.16$ & Seed & 4 & $74.65 \pm 1.45$ \\
\hline & 2 & $73.79 \pm 0.05^{\mathrm{bA}}$ & & 2 & $69.87 \pm 1.30^{\mathrm{aA}}$ \\
\hline & 1 & $60.26 \pm 10.0$ & & 1 & $68.75 \pm 0.62$ \\
\hline \multirow[t]{3}{*}{ Whole fruit } & 2 & $68.18 \pm 6.16^{\mathrm{bA}}$ & Whole fruit & 2 & $71.82 \pm 0.20^{\mathrm{aA}}$ \\
\hline & 1 & $64.80 \pm 3.73$ & & 1 & $69.87 \pm 2.13$ \\
\hline & 0.5 & $41.94 \pm 1.71$ & & 0.5 & $67.57 \pm 11.21$ \\
\hline \multirow[t]{3}{*}{ Quercetin } & 2 & $100.0 \pm 0.0$ & Trolox $\AA$ & 2 & $99.59 \pm 0.58$ \\
\hline & 1 & $92.40 \pm 0.30$ & & 1 & $95.26 \pm 6.71$ \\
\hline & 0.5 & $86.84 \pm 1.94$ & & 0.5 & $93 \pm 4.43$ \\
\hline
\end{tabular}

Data are the average of 3 replicates \pm standard deviation. Test of the fractions with average concentration of $2 \mathrm{mg} \mathrm{mL}^{-1}$. Lowercase letters compare between fractions and uppercase letters between the varieties. The same letters do not differ by Scott-Knott test at 5\% probability.

TABLE 7 -Linear regression analysis of polyphenol, total anthocyanin and vitamin C levels with antioxidant activity.

\begin{tabular}{lcccccc}
\hline \multirow{2}{*}{ Antioxidant } & \multicolumn{2}{c}{ Total polyphenols } & \multicolumn{2}{c}{ Anthocyanin } & \multicolumn{2}{c}{ Vitamin C } \\
\cline { 2 - 7 } Assay & Equation & $\mathrm{R}^{2}$ & Equation & $\mathrm{R}^{2}$ & Equation & $\mathrm{R}^{2}$ \\
\hline ABTS (Trolox $\AA)$ & $0.608+6.11 \mathrm{x}^{*}$ & 0.91 & $-0.368+098 \mathrm{x}^{*}$ & 0.69 & $156.258+4.29 \mathrm{x}^{*}$ & 0.74 \\
ABTS (vit. C) & $0.688+0.09 \mathrm{x}^{*}$ & 0.87 & $-0.345+0.013 \mathrm{x}^{*}$ & 0.63 & $156.137+0.91 \mathrm{x}^{*}$ & 0.73 \\
Phospho-molybdenum & $0.079+0.07 \mathrm{x}^{*}$ & 0.73 & $-0.639+0.014 \mathrm{x}^{*}$ & 0.38 & $147.416+0.81 \mathrm{x}^{*}$ & 0.65 \\
$\beta$-carotene/Ac. linoleic & $-13+0.29 \mathrm{x}^{*}$ & 0.40 & $-1.206+0.027 \mathrm{x}^{*}$ & 0.10 & $60.630+2.38 \mathrm{x}^{*}$ & 0.19 \\
\hline
\end{tabular}

*Significant at $\mathrm{P}<0.05$ by the $\mathrm{F}$ test.

\section{CONCLUSIONS}

1- The best method for extracting jabuticaba anthocyanins was maceration using $50 \%$ ethanol and/or 95\% ethanol acidified with $\mathrm{HCl} 1.5$ mol L $\mathrm{L}^{-1}(85: 15)$ using the proportion of $1: 15(1 \mathrm{~g}$ sample: $15 \mathrm{~mL}$ solvent). This results in a low $\mathrm{pH}$ extract, in which the anthocyanins were stable for the period of 185 days.

2- Jabuticaba skins are rich in anthocyanic pigments and present two anthocyanins: cyanidin 3-glucoside and delphinidin 3-glucoside.

3- The seeds and skins are good sources of vitamin $\mathrm{C}$, and could be used for the enrichment of foods and cosmetics.

4- The jabuticaba showed high antioxidant capacity, in the electron transfer methods, as well as in protection against lipid oxidation, having a potential to be used as an additive in the food industry, with possible benefits to consumer health.

\section{ACKNOWLEDGMENTS}

The authors thanks the Fundação de Amparo à Pesquisa do Estado de Minas Gerais (FAPEMIG) for financial support and fellowship (AJBL and MPM)

\section{REFERENCES}

ABDEL-ALL, E. S. M.; HUCL, P. Composition and stability of anthocyanins in blue-grained wheat. Journal of Agricultural and Food Chemistry, Easton, v. 51, n. 8, p. 2174-2180, 2003.

BOBBIO, F. O.; DRUZIAN, J. I.; ABRÃO, P. A.; BOBBIO, P. A.; FADELLI, S. Identificação e quantificação das antocianinas do fruto do açaizeiro (Euterpe aleracea) Mart. S. Ciência e Tecnologia de Alimentos, Campinas, v. 20, n. 3, p. 388-39, 2000. 
BORGUINI, R. G.; SILVA, M. V. O contéudo nutricional de tomates obtidos por cultivo orgânico e convencional. Higiene Alimentar, São Paulo, v.21, n. 41, p. 46, 2007.

CABRITA, L.; FOSSEN, T.; ANDERSEN, O. M. Color and stability of the six common anthocyanidin 3 -glucosides in aqueous solutions. Food Chemistry, London, v. 68, n. 1, p. 101-107, 2000.

DUARTE-ALMEIDA, J. M.; SANTOS, R. J.; GENOVESE, M. I.; LAJOLO, F. M. Avaliação da atividade antioxidante utilizando sistema $\beta$-caroteno/ ácido linoleico e método de sequestro de radicais DPPH'. Ciência e Tecnologia de Alimentos, Campinas, v. 26, n. 2, p.446-452, 2006.

EINBOND, L. S.; REYNERTSON, K. A.; LUO, X. D.; BASILE, M. J.; KENNELLY, E. J. Anthocyanin antioxidants from edible fruits. Food Chemistry, London, v. 84, n. 1, p. 23-28, 2004.

EMBRAPA. Agroindústria Tropical. Teste antioxidante de ABTS. 2007. Disponível em: $<\mathrm{http} / \mathrm{http}: / /$ www.cnpat.embrapa.br/>. Acesso em: 10 nov. 2008.

FERREIRA, D. F. Sisvar: versão 4. 6 (build 61) software. Lavras: Dex/UFLA, 2003. Disponível em: < http://www.dex.ufla.br/danielff/dff02.htm>. Acesso em: 18 jun. 2006.

FRANCIS, F. J. Food colorants: anthocyanins. Critical Reviews in Food Science and Nutrition, Cleveland, v. 28, n. 4, p. 273-314, 1989.

FULEKI, T.; FRANCIS, F. J. Extraction and determination of total anthocyanin in cranberries. Journal of Food Science, Chicago, v. 33, n. 1, p. 72-77, 1968.

GOMES, R. P. Fruticultura brasileira. 9: ed. São Paulo: Nobel, 1983. 446 p.

GUO, C.; YANG, J.; WEI, J.; LI, Y.; XU, J.; JIANG, Y. Antioxidant activities of peel, pulp and seed fractions of common fruits as determined by FRAP assay. Nutrition Research, v. 23, n. 12, p. 1719-1726, 2003.

HASSIMOTO, N. M.; GENOVESE, M. I.; LAJOLO, F. M. Antioxidant activity of dietary fruits, vegetables, and commercial frozen fruit pulps. Journal of Agricultural and Food Chemistry, Easton, v. 53, n. 8, p. 2.928-2.935, 2005.
HEIM, K. E.; TAGLIAFERRO, A. R.; BOBILYA, D. J. Flavonoids antioxidants: chemistry, metabolism and struture activity relationships. The Journal of Nutritional Biochemistry, Stonelam, v. 13, n. 9, p. 572-584, 2002.

HERNÁNDEZ, Y.; LOBO, M. G.; GONZÁLEZ, M. Determination of vitamin $\mathrm{C}$ in tropical fruits: a comparative evaluation of methods. Food Chemistry, London, v. 96, n. 4, p. 654-664, 2006.

HONG, V.; WROLSTAD, R. E. Use of HPLC separation/photodiode array detection for the characterization of anthocyanins. Journal of Agricultural and Food Chemistry, Easton, v. 38, n. 3, p. 708-715, 1990.

IACOBUCCI, G. A.; SWEENY, J. G. The chemistry of anthocyanins, anthocyanidins, and related flavilium salts. Tetrahedron Letters, Elmsford, v. 39 , n. 19 , p. $3005-3012,1983$.

JING, P.; GIUSTI, M. M. Effects of extraction conditions on improving the yield and quality of an anthocyanin - rich purple corn (Zea mays L.) color extract. Journal of Food Science, Chicago, v. 72, n. 6, p. 363-367, 2007.

KUBOLA J.; SIRIAMORNPUN, S. Phenolic contents and antioxidant activities of bitter gourd (Momordica charantia L.) leaf, stem and fruit fraction extracts in vitro. Food Chemistry, London, v.110, n. 4, p. 881-890, 2008.

KUSKOSKI, E. M.; ASUERO, A. G.; GARCIAPARILLA, M. C.; TRONCOSO, A. M.; FETT, R. Actividad antioxidante de pigmentos antociánicos. Ciência e Tecnologia de Alimentos, Campinas, v. 24, n. 4, p. 691-693, 2004.

LEE, H. S.; HONG, V. Chromatographic analysis of anthocyanins. Journal of Chromatography, Amsterdam, v. 624, n. 1/2, p. 221-234, 1992.

LEES, D. H.; FRANCIS, F. J. Standardization of pigment analyses in cranberries. Hortscience, Alexandria, v. 7, n. 1, p. 83-84, 1972.

LIMA, A. J. B.; CORRÊA, A. D.; ALVES, A. P. C.; ABREU, C. M. P.; DANTAS-BARROS, A. M. Caracterização química do fruto jabuticaba (Myrciaria cauliflora Berg) e de suas frações. Archivos Latinoamericanos de Nutrición, Caracas, v. 58, n.4, p.416-421, 2008. 
LIMA, V. L. A. G. de; GUERRA, N. B. Antocianinas: atividade antioxidante e biodisponibilidade. Boletim da Sociedade Brasileira de Ciência e Tecnologia de Alimentos, Campinas, v. 37, p. 121-128, 2003. Suplemento.

LIMA, V. L. A. G. de; MELO, E. A.; LIMA, D. E. S. Efeito da luz e temperatura de congelamento sobre a estabilidade das antocianinas da pitanga roxa. Ciência e Tecnologia de Alimentos, Campinas, v. 25, n. 1, p. 92-94, 2005.

MARKAKIS, P. Stability of anthocyanins in foods. In: MARKAKIS, P. (Ed.). Anthocyanins as food colors. New York: Academic, 1982. p. 163-180.

MAZZA, G. Anthocyanins in grape and grape products. Critical Review in Food Science and Nutrition, Cleveland, v. 35, n. 4, p. 341-371, 1995.

ODRIOZOLA-SERRANO, I.; HERNÁNDEZJOVER, T.; MARTÍN-BELLOSO, O. Comparative evaluation of UV-HPLC methods and reducing agents to determine vitamin $\mathrm{C}$ in fruits. Food Chemistry, London, v. 105, n.3, p.1151-1158, 2007.

PRATA, E.R.B.A.; OLIVEIRA, L.S..Fresh coffee husks as potential sources of anthocyanins. Food Science and Technology / Lebensmittel-Wissenschaft + Technologie, London, v. 40, p. 1555-1560, 2007.

PRIETO, P.; PINEDA, M.; AGUILAR, M. Spectrophotometric quantitation of antioxidant capacity trough the formation of a phosphomolybdenium complex: specific application to the determination of vitamin E. Analytical Biochemistry, New York, v. 269, n. 2, p.337-341, 1999.

RE, R.; PELLEGRINI, N.; PROTEGGENTE, A.; PANNALA, A.; YANG, M.; RICE-EVANS, C. Antioxidant activity applyng an improved ABTS radical cation decolorization assay. Free Radical Biology \& Medicine, New York, v. 26, n. 9/10, p. 1.231-1.237, 1999.
SILVA, P.A.;QUEIROZ, E.R.; ABREU, C.M.P.; SACZK, A.A. Desenvolvimento de metodologia analítica para determinação de vitamina $C$ em morango por HPLC. In: REUNIÃO ANUAL DA SOCIEDADE BRASILEIRA DE QUÍMICA, 2009, Fortaleza. Anais... CD-ROM

SUJA, K. P.; JAYALEKSHMY, A.; ARUMUGHAN, C. Antioxidant activity of sesame cake extract. Food Chemistry, London, v. 91, n. 2, p. 213-219, 2005.

TACO. Tabela Brasileira de Composição de Alimentos versão 2. Campinas: Unicamp, 2006. Disponível em:<http:/www.unicamp.br/nepa/taco/tabela. php? ativo=tabela\&PHPSESSID $=9$ be 42781 aa 5 e 5 ee 4 61c17c2c739d2160>. Acesso em: 01dez.2009

TREVISAN, L.M.; BOBBIO, F.O.; BOBBIO, P.A. Carbohydrates, organic acids and anthocyanins of Myrciaria jabuticaba, Berg. Journal of Food Science, Chicago, v.37, p. 818-819, 1972.

ZANATTA, C. F.; CUEVAS, E.; BOBBIO, F. O.; WINTERHALTER, P.; MERCADANTE, A. Z. Determination of anthocyanins from Camu-camu (Myrciaria dúbia) by HPLC-PDA, HPLC-MS, and NMR. Journal of Agricultural and Food Chemistry, Easton, v. 53, n. 24, p. 9.531-9.535, 2005.

YAMASHITA, F.; BENASSI, M. T.; TONZAR, A. C.; MORIYA, S.; FERNANDES, J. G. Produtos de acerola: estudo da estabilidade de vitamina C. Ciência e Tecnologia de Alimentos, Campinas, v.23, n.1, p.92-94, 2003. 